\title{
Influential aspects on seismic performance of confined masonry construction
}

\author{
Ajay Chourasia ${ }^{1^{*}}$, Sriman K. Bhattacharyya ${ }^{1}$, Pradeep K. Bhargava ${ }^{2}$, Navratan M. Bhandari ${ }^{2}$ \\ ${ }^{1}$ CSIR-Central Building Research Institute, Roorkee, India; ${ }^{*}$ Corresponding Author: ajayc@cbri.res.in \\ ${ }^{2}$ Department of Civil Engineering, Indian Institute of Technology Roorkee, Roorkee, India
}

Received 16 June 2013; revised 16 July 2013; accepted 23 July 2013

Copyright (C) 2013 Ajay Chourasia et al. This is an open access article distributed under the Creative Commons Attribution License, which permits unrestricted use, distribution, and reproduction in any medium, provided the original work is properly cited.

\begin{abstract}
Recent earthquakes around the world have resulted in loss of human lives and high economic losses due to poor performance of unreinforced masonry constructions as well as poorly-built reinforced concrete framed buildings. This has necessitated alternative building technologies with improved seismic performance. Confined masonry (CM) construction, has shown excellent behavior during past earthquakes across the world and requires similar skill at a marginally higher cost than that of unreinforced masonry. This paper summarizes the main features of generic construction and gains insight into the behavior of $\mathrm{CM}$ elements under earthquake excitations, representing a viable alternative for safe and economical construction in seismic areas. The paper discusses various influential aspects like sequence of construction, properties and type of masonry material, structural configuration, reinforcement detailing in tie column/beam and masonry, panel aspect ratio, interface between concrete and masonry, axial stress, multiple confining column, opening in wall panels and damage pattern etc. along with solution to overcome the limitations.
\end{abstract}

Keywords: Confined Masonry; Reinforcement Detailing; Panel Aspect Ratio; Masonry Interface; Multiple Confining Column; Damage Pattern

\section{INTRODUCTION}

The extensive use of masonry as a construction material in buildings is preferred due to its simplicity, durability, aesthetic appeal, material availability and economic advantages. In spite of associated edges, masonry exhibits distinct directional properties due to the strength of masonry units, mortar, thickness of mortar joints, interfacial bond strength between brick and mortar, moisture in the brick at the time of laying, arrangement of bricks, state of bricks before casting, curing, workmanship etc. Consequently, masonry structures display a complex mechanical behavior and perform badly in past earthquakes worldwide. Confined Masonry (CM) Construction technology, requires similar or locally available construction skills and materials and it may be used as an alternative for low to medium rise unreinforced masonry or RC framed structures. The confined masonry walls are in use since last seven to eight decade, wherein masonry is confined with slender tie column and bond beam elements without much knowledge about its function and behavior, however, researchers are involved in its investigation since 1973. Confined masonry comprises of masonry enclosed with lightly reinforced slender concrete columns and beams which are cast after the construction of the $900-1000 \mathrm{~mm}$ high wall with grooves ( 25 - 40 $\mathrm{mm}$ ) along edges so as to achieve better bonding at interface. Preliminary reports from January 12, 2010, Haiti earthquake (M 7.0); and February 27, 2010 Maule, Chile earthquake (M 8.8), documented good performance of confined masonry construction. In general, CM buildings may experience some damage in earthquakes, however, when properly designed and constructed, it sustains earthquake effects in an efficient manner when compared with masonry construction, with high degree of life safety.

On completion, CM construction resembles similar to RC framed construction with masonry infills. Conversely, these two construction systems are significantly different. The basic differences are in sequence of construction (Figure 1) and the way in which it resists gravity and lateral forces. In CM construction, confining elements are not designed or intended to act as a moment-resisting frame; thus detailing of the reinforcement is less convoluted. In general, confining elements are lightly reinforced in comparison with corresponding beams and 


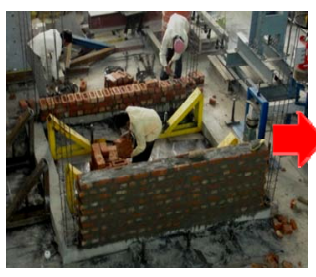

(a)

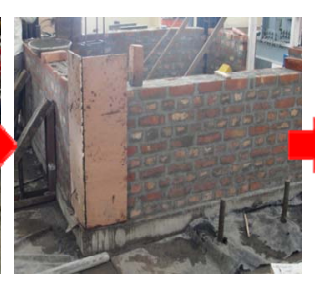

(b)

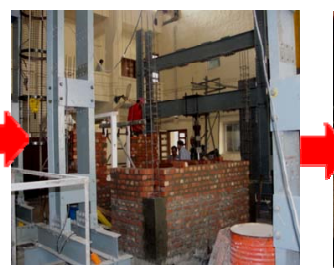

(c)

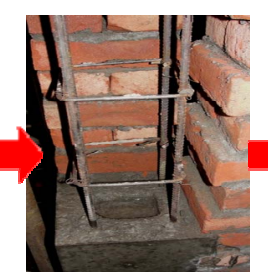

(d)

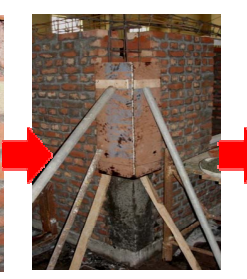

(e)

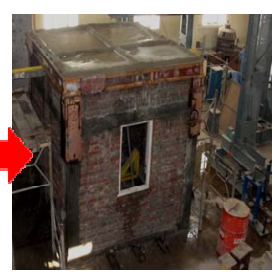

(f)

Figure 1. Sequence of construction of confined masonry building. (a) Construction of masonry wall with provision of reinforcement in tie column; (b) Providing shuttering on two faces of tie column; (c) Casting of tie column followed by subsequent masonry; (d) Provision of keys in concrete and masonry for better bonding of concrete with masonry; (e) Subsequent shutting of tie column; (f) Completed confined masonry model.

columns in RC framed structures. Thus, the walls in CM construction are load-bearing in nature while filler walls exists in RC frames which are not intended to carry load, this aspect results into economy of CM structural system.

The literature provides extensive information in isolation about the experimental and analytical evaluation of confined masonry walls dealing with different parameters to clarify failure patterns of walls, different unit types, effects of reinforcements in columns and walls on ultimate capacities, ductile behavior, energy dissipation capacity etc. [1-7]. Mostly these studies are on wall panels submitted to lateral displacement control loading combined in plane normal and shear. Meli [8] carried out tests on confined masonry panels to assess the shear strength, ductility and energy absorption capacity; Bernardini [9] reported the results of tests to clarify issues on stiffness degradation, crack evolution and energy dissipation; Luders and Hidalgo [10] performed cyclic tests in partly and fully grouted CM walls to study the effect of reinforced horizontal mortar joints; Tomazevic and Lutman [11] presented study on seismic resistance of reinforced masonry walls; Sanchez and Astroza [12] studied the behavior under cyclic loading and quantified the confining improvement; Kumazwa [13], Yoshimura [14] studied non-linear characteristics of CM wall with lateral reinforcement in mortar joint at corner part of wall; Yoshimuara [15] again evaluated effect of wall reinforcement subjected to lateral forces at different heights and axial load; Yanez [16] showed the comparison of CM wall panels made of hollow concrete and clay brick masonry unit with four cases of openings; Zabala [17] presented a complete study on CM walls with different column reinforcement; Marinilli [18] presented the results of four full-scale wall panels with 2, 3, and 4 tie columns under reversed cyclic lateral and constant vertical load; Gouveia and Lourenco [6] reported test results on CM walls showing influence of confinement, horizontal reinforcement and different kinds of units; Wijaya [19] presented a complete study on CM walls with grooves at interface of masonry and tie column, short anchor between column-wall and continuous anchorage embedded in mortar joint and RC column and carried out comparative study with reinforced concrete frame with masonry infill. Meanwhile, the knowledge of various parameters of CM walls under cyclic loading is very scanty. The objective of this paper is to contribute to a comprehensive understanding of seismic behavior of CM construction and to overcome seismic deficiencies.

This paper attempts to summarize the main features of generic construction and gains insight into the seismic behavior of CM elements, representing a viable alternative for safe and economical construction in seismic areas. The paper outlines in various influential aspects like sequence of construction, properties and type of masonry material, structural configuration, reinforcement detailing in tie column/beam and masonry, panel aspect ratio, interface between concrete and masonry, axial stress, multiple confining column, opening in wall panels and damage pattern etc. along-with the solution to overcome the limitations.

\section{SEISMIC BEHAVIOUR}

Due to lack of standards and design procedures for confined masonry construction, besides technological motivations, such typology are not widely used as a structural system in spite of its adequate economy in construction and exhibit excellent seismic performance in past earthquakes. The various key constituents and procedure of construction of confined masonry contributing for seismic behavior are discussed in subsequent sections.

\subsection{Characteristics of Masonry Unit and Mortar}

Masonry is a heterogeneous material which consists of units and joints. Units are such as clay bricks, blocks, ashlars, while mortar can be clay, bitumen, chalk, lime/cement based mortar. The huge number of possible combinations emerged out by the geometry, nature and arrangement of units, characteristic of mortar makes masonry a complex mechanism. The compressive 
strength of units and mortar is a good indicator of the general quality of material and thereby masonry strength. In addition, most popularly solid burnt clay bricks are used as units due to its numerous advantages viz. cost, availability, traditional knowledge etc., which possess better seismic features as compared to their hollow, concrete blocks and calcium silicate units [20]. The use of hollow units is not favored in high seismic zones due to inherent brittle behavior that could be ascribed to their high rigidity.

Masonry exhibits distinct directional properties due to the strength of masonry units, mortar, thickness of mortar joints, interfacial bond strength between brick and mortar, moisture in the brick at the time of laying, arrangement of bricks, state of bricks before casting, curing, workmanship etc. It is also observed that there is wide variation in elastic modulus and compressive strength of units and cement mortar (1:6) adopted for the construction across the world and in general the brick masonry strength increases with increase in brick/mortar strength. Thus, the compatibility of elastic modulus of units and mortar is important parameter responsible for cracks propagation through constituent materials of masonry. In addition, low shear strength of bricks in comparison to mortar leads to inclined cracks mainly passing through units causing possibility of masonry crushing at high seismic loads.

\subsection{Masonry Walls}

While dealing the design of CM construction, wall density i.e. ratio of total wall area in each principal direction to floor area, is one of the criterion for adequate load resistance. Further, the effect of earthquake forces depends on number of stories, seismicity, soil conditions, construction material, adequate design provisions, detailing of structural elements and the code used as the basis of design. Based on analytical studies, minimum wall density of $1.15 \%$ for moderate wall damage and $0.85 \%$ for light wall damage is essentially required to be provided in each principal direction [4].

Further, wall density per unit weight i.e. wall density in the first storey divided by total weight of the structure, is another criteria as suggested by Moroni [21], as a better measure of seismic resistance than that of wall density. It earmarks minimum density per unit weight to confine low damage in walls as $0.018 \mathrm{~m}^{2} /$ ton while for moderate damage the corresponding value shall be $0.012 \mathrm{~m}^{2} /$ ton. It is clear that to present extensive damage to CM construction under severe shaking, adequate wall densities are desirable in both principal directions. It is to be noted that high wall density is better in load-carrying capacity under gravity, however limits deformation demands under seismic loads. Thus, incorporating more wall area in is not necessarily the proposition for improving seismic performance.

\subsection{Confining Members}

The improvement in seismic performance of CM walls in comparison to URM walls is primarily achieved by the provision of tie column and tie beams confining masonry panel, which mainly preventing premature wall disintegration after formation of crack in masonry [14,22]. Also it reduces rate of stiffness degradation to large extent thereby enhancement in deformation and energy dissipation characteristics. The other governing factors influencing the effectiveness of confining elements are location, type, size, shape, reinforcement detailing, grade of concrete and the number of tie columns and bond beams.

Mainly minimum longitudinal reinforcement in tie column is provided to avoid predominance of flexural deformation as a result of rebar yielding at end regions [17]. Eurocode-8 [23] suggests the minimum longitudinal reinforcement in tie column and beams as $1 \%$ of cross-sectional area. It is obvious that increase in amount of tie column reinforcement substantially increases load carrying capacity of CM constructions, hence corner tie columns at first storey level are to be provided with large reinforcement ratio especially when it is founded on firm soil. However, excessively large reinforcement in tie column is not always a right choice as it may trigger brittle shear failure mode. On the other hand, closely spaced lateral ties in tie column with adequate (70 mm long) hook length provides confinement to the core concrete resulting into increase of deformability and energy dissipation of the system. In general, the detailing of reinforcement in tie column is illustrated at Figure 2 [4].

\subsection{Interface between Masonry and Concrete}

The seismic performance of CM construction improves with the effective bonding at interface between tie columns and confined masonry panels. Figure 3 illustrates that when concrete-masonry adherence merely provides the required bond under the influence of lateral

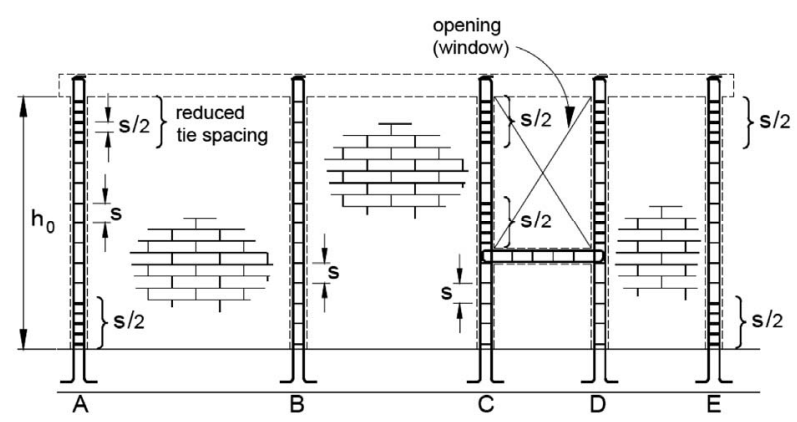

Figure 2. Tie-column reinforcement detailing-reduced tie spacing at end region [4]. 


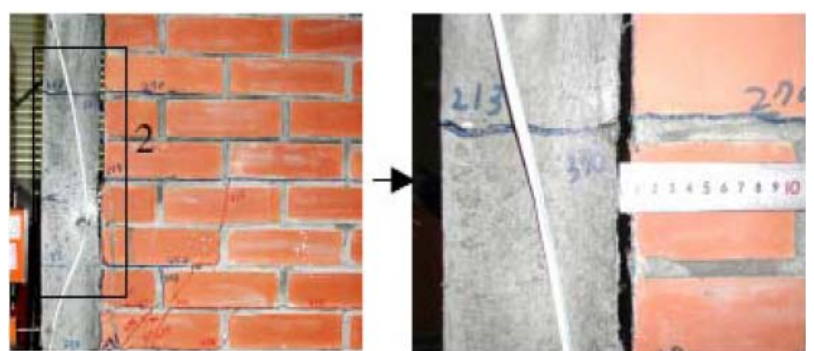

Figure 3. Separation of masonry-concrete element at interface [14].

loads and occurrence of vertical separation and partial disintegration of the panel and confining elements at large deformations, which adversely affect the seismic performance of CM walls [14].

To overcome above problem, casting concrete against toothed ( 25 - $40 \mathrm{~mm}$ or 1.5 times the average size of course aggregate in concrete) at masonry and concrete interface can be provided which act as shear keys. Alternatively, providing the $\mathrm{CM}$ wall with connection rebar (U-shape or L-shape rebar that are anchored adequately into walls) helps to improve the bond and load transfer/deformation capacity [24]. Experimental tests performed on CM model by the authors demonstrates the formation of $0.5 \mathrm{~mm}$ wide crack at toothed interface between tie column and masonry at a very later stage of formation of cracks in masonry panel (Figure 4). The interface effectiveness can also be enhanced by provision of $6 \mathrm{~mm}$ dia (450 $\mathrm{mm}$ long) reinforcement as dowel adequately embedded in tie column concrete and masonry mortar at every $5^{\text {th }}$ course.

\subsection{Aspect Ratio}

Aspect ratio of masonry panel (height to length) is one of the governing factors from damage pattern and failure mode consideration of CM walls. Squat CM walls with aspect ratios around one are commonly used in practice and its seismic behavior is mostly governed by shear deformations [25]. Nevertheless, as the aspect ratio increases, the flexural deformations become more dominant, leading to early crack formation and higher stiffness degradation, thereby affecting strength characteristics of the panel. For slender CM walls, flexural deformations greatly outdo those of shear, and, therefore, these walls are likely to fail in flexural mode. As a consequence, squat CM walls possess lower deformability as compared to its counterpart. While this aspect is of paramount importance, it has been overlooked in many codes and regulations that address seismic behavior of CM walls [26].

\subsection{Openings Size}

A typical masonry wall when subjected to earthquake

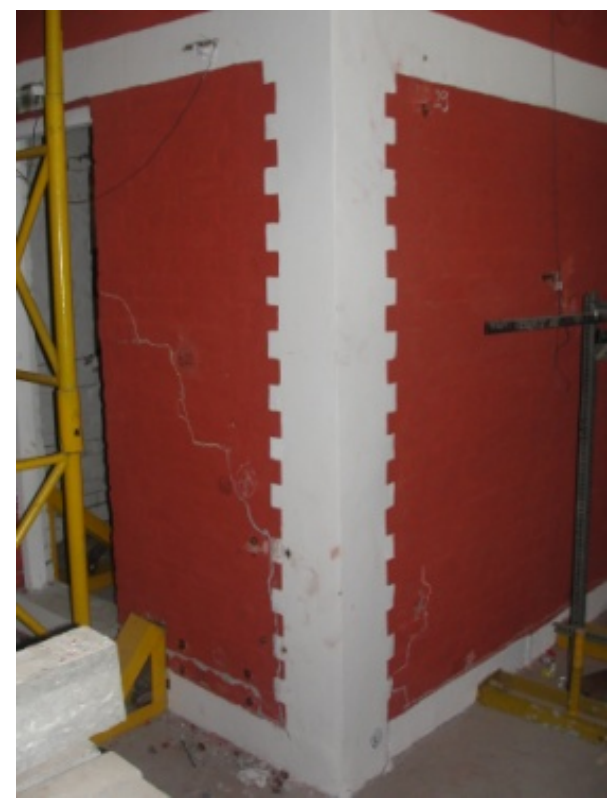

Figure 4. Effectiveness of toothed interface between tie column and masonry.

load, usually initiate shear cracks at the corners of openings and extends towards the middle of piers. Further, crushing of masonry units at corners is also a common phenomenon at higher loads. Thus, size, shape, location and confinement detailing of openings have a great impact on the seismic performance. The stiffness of walls with an opening ratio around $11 \%$ of total wall area is close to that of the specimen without openings [16].

\subsection{Horizontal Reinforcement in Masonry}

The provision of horizontal reinforcement in masonry panel influences the uniform distribution of cracks and improves shear resistance, deformation capacity, and energy dissipation characteristics of CM walls (Figure 5). Moreover, the rate at which stiffness and strength degrade will substantially decline, and therefore, more stable response curves are achieved, even at large deformation levels.

The ratio between horizontal reinforcement in masonry panel to longitudinal reinforcement of tie column should be dealt judiciously so as to avoid the high possibility of flexural failure mode in case of over-reinforced walls [17]. As a result of provision of horizontal reinforcement in masonry, delayed emergence of inclined cracks and spreading of shear cracks at the toe of wall were also noticed during various tests. When there is insufficient reinforcement at first-storey panels, fracture of rebar occurs near inclined cracks and in the mid part of the wall resulting into sliding of upper walls over the cracks [3].

The test results advocate horizontal reinforcement ratio in wall between $0.005-0.017$, with an optimum value 


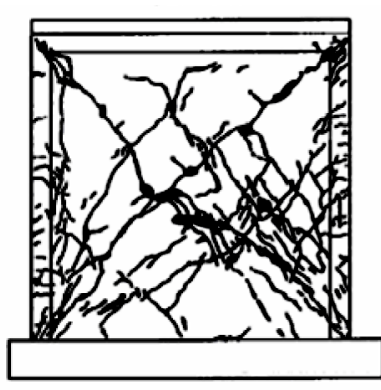

(a)

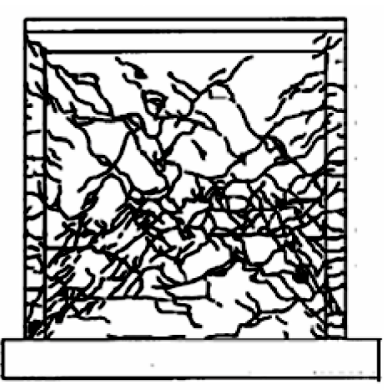

(b)
Figure 5. Comparison of crack pattern for masonry panel without and with horizontal rebar [3]. (a) $0 \%$; (b) $0.71 \%$ panel reinforcement.

of about 0.01 [1]. The tests also indicate that with small horizontal reinforcement in the masonry panel, the crack widths are quite large for small inter-story drift. In order to keep the crack widths under $1.5 \mathrm{~mm}$, the inter-story drift ratio should be limited to $1 \%$, while for crack widths under $3.0 \mathrm{~mm}$ the inter-storey drift should be no larger than $2 \%$ [27].

\subsection{Axial Loads}

Axial loading are also one of the influential parameter responsible for increase in shear and energy dissipation capacity of CM construction. The effect is more distinct for the unreinforced (in both vertical and horizontal direction) masonry panels [28]. On the contrary, in case of excessively high axial loads i.e. more than masonry compressive strength, the ultimate deformation capacity is adversely affected. Therefore, the performance of CM construction can be enhance by proper planning of square and regular grids of structure in plan and vertical direction, use of two-way slab, uniform distribution of gravity loads [29].

\subsection{Multiple Confining Columns}

The presence of more than two confining-columns in CM wall is very common due to limitation in length of masonry panel. From the experimental results [18], it is evident that the presence of more confining columns in walls of the same global dimensions increases the initial stiffness. However, it is important to note that after stiffness degradation process, the similar residual stiffness is observed in all cases. Further, inclusion of multiple confining columns in walls, tends to increases the initial stiffness, system ductility, strength, and allows better damage distribution in masonry panels. However, inclusion of confining columns does not improve energy dissipation capacity or equivalent damping ratio, mainly due to its dependence on friction between horizontal mortar joint. The occurrence of crack in multiple confining case of $\mathrm{CM}$ construction is similar to single $\mathrm{CM}$ wall panel i.e. cracks are primarily along the horizontal and vertical mortar joints in zig-zag fashion, following a $45^{\circ}$ inclination path.

\subsection{Damage Pattern of CM Walls}

The CM walls can be approximated as elastic shear beam whose stiffness is provided jointly by masonry panel and confining elements regardless of stiffness decay due to initiation of flexural cracks in tie columns and micro-cracks in masonry $[2,7,30]$. Masonry being a brittle material, the stiffness of masonry decreases drastically after formation of crack and further its extension towards the middle of solid panels. Mostly, these cracks pass through mortar joints in a zig-zag pattern [7,18], and at few locations through the bricks as well where compressive strength of bricks is relatively low.

The response of post-cracking behavior of CM walls mainly governed by shear deformations, which is directly influenced by friction at mortar joint (bed and head joints), brick interlock, and shear resistance of tie column at end region [31]. Figure 6 shows the cracking limit state in CM panel by formation of tension in tie column and compression strut in masonry. Also it is seen that due to lightly reinforced tie column and high aspect ratio of masonry there is a high possibility of flexural deformation in masonry leading to sliding shear and its extension into tie column end (Figure 6(b)), at peak point of the response i.e. maximum load state. Thus, cracked wall pushes tie columns sideways, and produces permanent tension [22,32], while the masonry panel, is subjected to more compressive stresses, provided that an adequate bond allows sufficient load transfer between wall and confining elements.

At large deformation, generally partial separation of masonry and confining elements [17] followed by crushing of masonry at mid panel at high strain location occurs. Subsequently, penetration of cracks into masonry units [22,32] also occurs due to increase in bending stress of units. At the same time, tie column also suffers with extensive concrete cracking/crushing, and rupture/buckling of longitudinal bars at end region [2]. As a result, there is considerable degradation of stiffness, to the tune of $20 \%$ of its initial stiffness [2]. In case of multi-storyed CM constructions, concentration of damage is relatively more at first story due to the softening action, which may be attributed to the higher shear span ratio. Thus, the damage at first-story can be minimized by increasing energy absorption capacity through proper confinement and provision of horizontal reinforcement at joint $[2,7,22,32]$.

To prevent these cracks from opening up considerably, drift capacity of CM walls are to be controlled [33] to reasonable extent. This can be overcome by providing horizontal reinforcement in mortar joint and continuing 


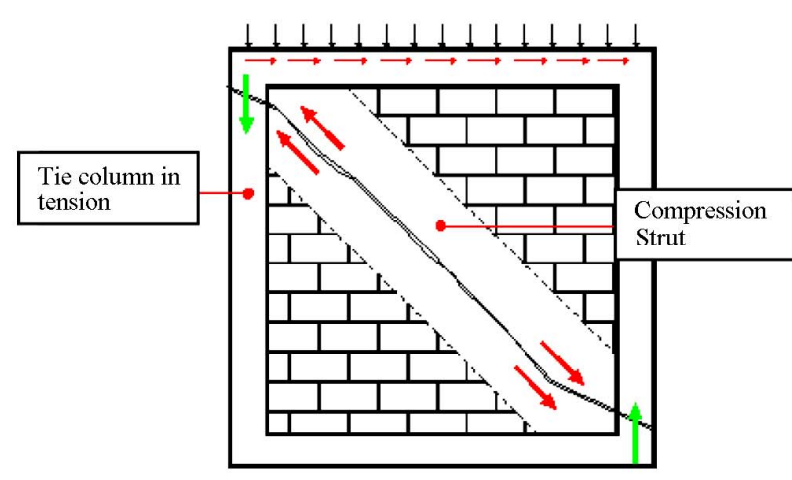

(a)

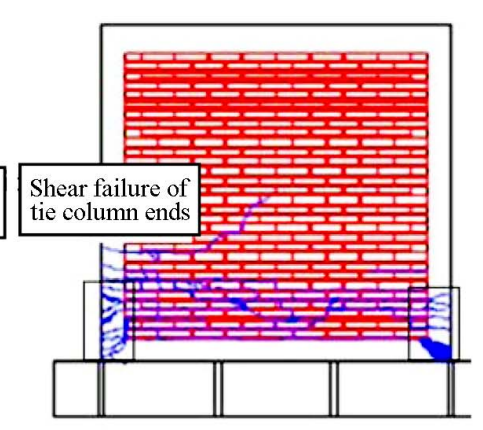

(b)

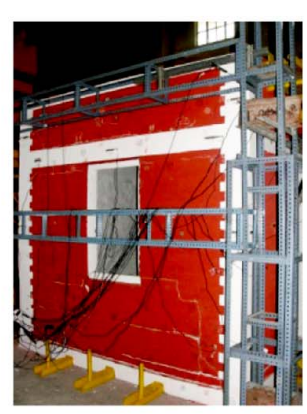

(c)

Figure 6. Failure mode of CM panel (a) at cracking limit state (b) flexure failure (c) [17].

through tie columns and placing closely spaced lateral ties in tie column with $135^{\circ}$ hooks of adequate length.

\section{CONCLUSIONS}

Confined masonry is a most suitable building typology for low to medium rise construction. The paper attempted to discuss various aspects of influencing performance of confined masonry typology, under seismic events and solutions that could be incorporated to overcome. The past earthquakes, including major ones and laboratory tests on CM walls demonstrate the effectiveness in terms of strength and ductility of confined masonry system over unreinforced masonry. Furthermore, it is indicated that the performance of confined masonry not only depends on system of construction but also on the properties and masonry type, material and structural configuration, reinforcement detailing in tie column, beam and masonry, panel aspect ratio, interface of concrete and masonry, axial loads, and multiple confining elements etc. Therefore, the influential aspects are investigated based on damage pattern and limitations. These limitations are overcome by adopting suitable approaches like provision of horizontal reinforcement in masonry, dowels at interfaces, ductile detailing of reinforcement in tie-column etc.

The study reveals that significant attention has been given to understand behavior of tie column, in-plane wall panels. However much less attention has been given to aspects like out-of-plane seismic behavior, characteristics of bond beams, opening confinement, size and shape of opening etc. To deeply reveal the seismic performance of confined masonry construction, rigorous experiments should be conducted on full-scale model buildings for better understanding of the system and to relax stringent provisions in the design. In addition, the studies needed to assess the vulnerability of existing CM constructions, to define economical rational design rules, and to draw road-map for future confined masonry construction.

\section{ACKNOWLEDGEMENTS}

Authors gratefully acknowledge Council of Scientific \& Industrial Research (CSIR), New Delhi for promoting R\&D in earthquake engineering at CSIR-Central Building Research Institute (CBRI), Roorkee, India.

\section{REFERENCES}

[1] Alcocer, S.M. and Zepeda, J.A. (1999) Behavior of multi-perforated clay brick walls under earthquake type loading. 8th North American Masonry Conference, Austin, 6-9 June 1999, 235-246.

[2] Alcocer, S.M., Arias, J.G. and Vazquez, A. (2004) Response assessment of Mexican confined masonry structures through shaking table tests. 13th World Conference on Earthquake Engineering, Vancouver, 1-6 August 2004, 13 Pages.

[3] Aguilar, G., Meli, R., Diaz, R. and Vazquez-del-Mercado, R. (1996) Influence of horizontal reinforcement on the behaviour of confined masonry walls. 11th World Conference on Earthquake Engineering, Acapulco, 23-28 June 1996, No. 1380.

[4] Brzev, S. (2007) Earthquake resistant confined masonry construction. National Information Centre of Earthquake Engineering, Kanpur.

[5] Gostic, S. and Zarnic, R. (1999) Cyclic lateral response of masonry infilled RC frames and confined masonry walls. Proceedings of the 8th North American Masonry Conference, Austin, 3-6 June 1999, 477-488.

[6] Gouveia, J.P. and Lourenco, P.B. (2007) Masonry shear walls subjected to cyclic loading: Influence of confinement and horizontal reinforcement. 10th North American Masonry Conference, Missouri, 3-6 June 2007, 838-848.

[7] Irimies, M.T. (2002) Confined Masonry Walls: the influence of the tie-column vertical reinforcement ratio on the seismic behaviour. The Proceedings of the 12th European Conference on Earthquake Engineering, London, 9-13 September 2002, 241 Pages.

[8] Meli, R. (2003) Behavior of masonry walls under lateral loads. Proceedings of the 5th World Conference on Earthquake Engineering, Rome, 25-29 June 1973, Paper 101a. 
[9] Bernardini, A., Modena, C., Turnesek, V. and Vescovi, U. (1980) A comparison of three laboratory tests.

[10] Luders, C. and Hidalgo, P. (1986) Ïnfluencia dei refuerzo horizontal en el comportamiento seismico de muros de albanileria armada. Cuartas Jornadas Chilenas de Sismologia e Ingenieria Antisismica, 2, H139-H158.

[11] Tomazevic, M. and Lutman, M. (1988) Seismic resistance of reinforced masonry walls. Proceedings of the 9th World Conference on Earthquake Engineering, Japan As, for Earthquake Disaster Prevention, Tokyo, 2-9 August 1988, VI/97-102.

[12] Sanchez, T.A., Flores, L.E., Leon F., Alcocer S.M. and Meli, R. (1992) Respuesta sismica de muros de mamposteria confinada con diferentes grados de acoplamiento a flexion. CENAPRED, Informe ES/02/91, 106 Pages.

[13] Kumazava, F. and Ohkubo, M. (2000) Nonlinear characteristics of confined masonry wall with lateral reinforcement in mortar joints. Proceedings of the 12th World Conference on Earthquake Engineering, Auckland, Paper No. 743.

[14] Yoshimura, K., Kikuchi, K., Kuroki, M., Nonaka, H., Kim, K.T., Matsumoto, Y., et al. (2003) Experimental study on reinforcing methods for confined masonry walls subjected to seismic forces. 9th North American Masonry Conference, Clemson, 1-4 June 2003, 89-100.

[15] Yoshimura, K., Kikuchi, K., Kuroki, M., Liu, L. and Ma, L. (2000) Effect of wall reinforcement, applied lateral forces and vertical axial loads on seismic behavior of confined concrete masonry walls. 12th World Conference on Earthquake Engineering, Paper No. 0984.

[16] Yanez, F., Astroza, M., Holmberg, A. and Ogaz, O. (2004) Behavior of confined masonry shear walls with large openings. 13th World Conference on Earthquake Engineering, Vancouver, 1-6 August 2004, Paper No. 3438.

[17] Zabala. C., Honma, C., Gibu, P., Gallardo, P. and Huaco, G. (2004) Full scale on line test on two story masonry building using handmade bricks. 13th World Conference on Earthquake Engineering, Vancouver, 1-6 August 2004, 14 Pages.

[18] Marinilli, A. and Castilla, E. (2004) Experimental evaluation of confined masonry walls with several confining-columns. 13th World Conference on Earthquake Engineering, Vancouver, 1-6 August 2004, 12 Pages.

[19] Wijaya, W., Kusumastuti, D., Suarjana, M., Rildova and Pribadi, K. (2011) Experimental study on wall-frame connection of confined masonry wall. Procedia Engineering, 14, 2094-2102. doi:10.1016/j.proeng.2011.07.263

[20] Alcocer, S.M., Arias, J.G. and Vazquez, A. (2003) The New Mexico City building code requirements for design and construction of masonry structures. The Proceedings of the 9th North American Masonry Conference, Clemson, 1-4 June 2003, 656-667.

[21] Moroni, M., Astroza M. and Caballero, R. (2000) Wall density and seismic performance of confined masonry buildings. TMS Journal, 18, 81-88.

[22] Tomazevic, M. and Klemenc, I. (1997) Seismic behaviour of confined masonry walls. Earthquake Engineering and Structural Dynamics, 26, 1059-1071. doi:10.1002/(SICI)1096-9845(199710)26:10<1059::AIDEQE694>3.0.CO;2-M

[23] European committee for standardization (2002) European standard.

[24] Arya, A.S. (2000) Non-engineered construction in developing countries-An approach toward earthquake risk reduction. Proceedings of the 12th World Conference on Earthquake Engineering, 33, 187-208.

[25] Alvarez, J.J. (1996) Some topics on the seismic behaviour of confined masonry structures. 11th World Conference on Earthquake Engineering, Acapulco, Paper No. 180.

[26] Meli R., Svetlana Brzev, et al. (2011) Seismic design guide for low rise confined masonry buildings. EERI \& IAEE, Tokyo.

[27] Moroni, M., Astroza M. and Mesias, P. (1996) Displacement capacity and required story drift in confined masonry buildings. 11th World Conference on Earthquake Engineering, Acapulco, Paper No. 1059.

[28] Ishibashi, K., Meli, R., Alcocer, S.M., Leon, F. and Sanchez, T.A. (1992) Experimental study on earthquake-resistant design of confined masonry structures. Proceedings of the 10th World Conference on Earthquake Engineering, Madrid, 19-24 July 1992, 3469-3474.

[29] Bariola, J. and Delgado, C. (1996) Design of confined masonry walls under lateral loading. 11th World Conference on Earthquake Engineering, Acapulco, Paper No. 204.

[30] Gibu, P. and Zavala C. (2002) The current state-of-the-art of masonry and adobe building in Peru. Japan Peru Center for Earthquake Engineering Research and Disaster Mitigation, Lima.

[31] Flores, L.E. and Alcocer, S.M. (1996) Calculated response of confined masonry structures. 11th World Conference on Earthquake Engineering, Acapulco, Paper No. 1830.

[32] Tomazevic, M. and Klemenc, I. (1997) Verification of seismic resistance of confined masonry buildings. Earthquake Engineering and Structural Dynamics, 26, 10731088.

doi:10.1002/(SICI)1096-9845(199710)26:10<1073::AIDEQE695>3.0.CO;2-Z

[33] Alcocer, S.M. (1996) Implications derived from recent research in Mexico on confined masonry structures. Worldwide Advances in Structural Concrete and Masonry: Proceedings of the CCMS Symposium Held in Conjunction with Structures Congress XIV, Chicago, 15-18 April 1996, 82-92. 